\title{
Exogenous Protein as an Environmental Stimuli of Biofilm Formation in Select Bacterial Strains
}

\section{Donna Ye ${ }^{1}$, Lekha Bapu ${ }^{1}$, Mariane Mota Cavalcante ${ }^{2}$, Jesse Kato ${ }^{1}$, Maggie Lauria Sneideman ${ }^{3}$, Kim Scribner $^{4}$, Thomas Loch $^{4} \&$ Terence L. Marsh ${ }^{1 *}$}

1 Department of Microbiology and Molecular Genetics, Michigan State University, East Lansing, MI

2 Department of Biology, Universidade Federal de São Carlos, Sorocaba - SP, Brazil

3 Department of Biology, Kalamazoo College, Kalamazoo MI

4 Department of Fisheries and Wildlife, Michigan State University, East Lansing, MI

*Correspondence may be addressed to T.L. Marsh (marsht@msu.edu)

\section{ABSTRACT}

A screening of environmental conditions that would elicit robust biofilm in a collection of Serratia marcescens isolated from soil revealed that exogenous milk protein increased biofilm productivity up to ten-fold. A select screening of fish pathogens, freshwater and human isolates identified several other species that responded similarly to exogenous protein. The optimal protein concentration was species specific; S. marcescens at 5\% milk protein, Aeromonas sp. at 2-3\%, Flavobacterium columnare at 1\% and Pseudomonas aeruginosa at 0.1-0.4\%. Media supplemented with milk protein also increased the cell counts in biofilm as well as the protein incorporated into the biofilm matrix. These data suggest that relatively high concentrations of exogenous protein may serve as an environmental trigger for biofilm formation, particularly for pathogenic bacteria exposed to relatively high concentrations of protein in bodily fluids and mucosal surfaces.

\section{INTRODUCTION}

Since the concept of biofilm was first viewed through the eyes of molecular microbiology three decades ago, our appreciation of its importance in ecology has grown exponentially. We now recognize biofilm as an alternative life strategy for many, if not all species of microbes across three domains. The importance of biofilm in industry(1), public health (2), medicine(3-5) and the environment $(6,7)$ have been well documented, leading us to frequently include the analysis of a bacterial strain's ability to form biofilm as part of its species' description.

Growth of a microbe in a biofilm removes it from a pelagic lifestyle that is characterized by mass action events (or close to it). As a pelagic entity, change in location and concomitant change 
38 in access to nutrients could happen quickly. Once attached to a surface and embedded in a 39 macromolecular matrix, a very different lifestyle ensues - one in which the tempo and mode of 40 life is slowed, the ambient conditions change more gradually (in general) and cell physiology is 41 altered (8).

42 Biofilm, as part of a life history, is reversible $(3,9,10)$. A pelagic microbial species can attach 43 to a substratum, multiply and then return to the surrounding solution as the biofilm structure 44 becomes more susceptible to turbulence or the bacterium senses suboptimal conditions for sessile 45 life. Environmental signals play an essential role in informing the microbe so that optimal survival strategies are selected for, including attachment and release. Consistent with the substantial phylogenetic and physiological diversity of the microbial world, biofilm, as an eco/evo strategy, has been employed in many different ecosystems in response to a broad range of environmental conditions. Of interest to us are specific environmental signals that elicit behavioral changes leading to the formation of biofilm. There are logical candidates for signals including carbon and energy sources, essential micronutrients and even inhibitors. For example, in Janthinobacterium, both violacein and biofilm production were stimulated by glycerol and inhibited by glucose (11). The presence of calcium ion has also been found to influence biofilm productivity in Pseudomonas (12), Pseudoalteromonas (13), Xyella (14) and Citrobacter (15). In addition, $\mathrm{CaCl}_{2}, \mathrm{MgCl}_{2}, \mathrm{CuSO}_{4}$, sucrose and sodium dodecyl sulfate produced greater biofilm in Yersinia pestis (16). In some circumstances it is difficult to distinguish between a primary trigger and a secondary adjuvant of biofilm formation.

We report herein on two converging lines of investigation in our laboratory, the identification of environmental signals for biofilm formation in a collection of Serratia isolated from soil, and in several fish bacterial pathogens. Our observations with Serratia clearly indicated that exogenous skim milk protein at relatively high concentrations was sufficient to stimulate biofilm formation ten-fold. We extended this observation to Flavobacterium columnare, Aeromonas salmonicida, two fish pathogens, as well as a collection of freshwater isolates. We also observed that exogenous protein had little or no effect on some isolates from mammalian hosts, but stimulated others. These 66 
MATERIAL AND METHODS

Strains and cultivation. Pseudomonas aeruginosa PA01 was a gift of Dr. M. Bagdasarian (MSU). Hydrogenophaga F14, Brevundimonas F16, Acidovorax F19 and Pseudomonas strain C22 were isolated from lake sturgeon eggs (17) and Serratia marcescens strains RL-1-RL16 were selected on Pseudomonas Isolation Agar (Difco) from soil under an arborvitae on the Michigan State University campus in East Lansing, MI (GenBank Accession MF581042-MF581057). The strains described in Figures $2 \& 3$ were isolated from the Red Cedar River on the Michigan State University (MSU) campus by selection on Pseudomonas Isolation agar (GenBank Accession MG386765-MG386811). Flavobacterium columnare 090702-1 and Aeromonas strain 060628-1 were provided by Dr. Thomas Loch at MSU and were from fish necropsies. Aeromonas strain SM, unpigmented Serratia and the low biofilm forming Escherichia coli were isolated from human feces (18) and generously provided by Dr. Shannon Manning at MSU, as was the high biofilm forming bovine E. coli isolate. Isolates were stored at $-80^{\circ} \mathrm{C}$ and resuscitated on Trypticase Soy Agar (Difco) or R2A (Difco). Broth cultures when needed were grown on either TSB or R2B (Difco R2A recipe without agar). Media supplemented with milk protein (Hardy Diagnostics) was made by first sterilizing 2x media stocks (TSB or R2B) and 2x milk protein in separate bottles and then mixing the two shortly after removing the liquids from the autoclave.

Phylogenetic analysis. The rRNA of S. marcescens strains (RL-1-RL-16) specific to this study were sequenced at the MSU genomics facility using the 27F 16S rRNA primer (Sanger chemistry). The Serratia sequences (RL-1 through RL-16) were initially screened with the Ribosomal Database Project Classifier and Sequence Match (19). Phylogenetically related Proteobacteria sequences were downloaded from the Ribosomal Database project and analyzed along with the Serratia sequences (RL-1 - RL-16) in SeaView V4 (20) using BioNJ with HKY distance correction and Maximum Likelihood. The maximum likelihood tree and results from Classifier and Sequence Match are presented in the supplementary materials. All strains isolated from the Red Cedar River were identified by $16 \mathrm{~S}$ rRNA sequencing using the 27F primer and identified using Sequence Match and Classifier in the Ribosomal Database Project (19).

Standard Biofilm Assay. The protocol for biofilm measurement as described by Merritt et al.

99 (Corning Costar) depending on the specific experimental requirements. The 24 well plates were 
101 determined. Overnight cultures of strains in either Typticase Soy Broth (Difco) or R2B (3-5 mls) 102 were grown at $25^{\circ} \mathrm{C}$ in a rotating rack (Cole-Parmer). Sterile broth $(75-100 \mu 1)$ was added to all 103 wells and then $50-75 \mu 1$ of broth culture was inoculated into the wells. In all experiments, the 104 amount of culture and broth totaled $150 \mu \mathrm{l}$ for 96 well plates. When using 24 well plates for cell 105 growth measurements, $750 \mu 1$ of sterile broth and $50 \mu 1$ of overnight culture were added to all wells, excluding the uninoculated controls. When using 24 well plates for cell and protein concentrations,

$107700 \mu \mathrm{l}$ of sterile broth and $100 \mu \mathrm{l}$ of overnight broth culture were added to all wells, excluding the 108 uninoculated controls. After inoculation, plates were sealed with sterile foil (VWR) and incubated at $25^{\circ} \mathrm{C}$ on an orbital shaker $(100 \mathrm{rpm})$ for 24 or 48 hours depending on the experiment. After 110 incubation, the seal was removed and when processed for biofilm determination, the plates were 111 washed gently (x3) in reverse osmosis (RO) water as described by Merritt et al. (21), stained with $112150 \mu \mathrm{l}(800 \mu \mathrm{l}$ for 24 well plates $)$ of $0.5 \%$ filtered ( $0.2 \mu$ filter) crystal violet for 15 minutes, washed $113 \mathrm{x} 3$ in RO water, blotted and allowed to dry overnight in the dark. The following day $150 \mu 1$ of $30 \%$ 114 acetic acid was added to each well $(800 \mu \mathrm{l}$ for 24 well plates $)$ and the plate was incubated for 25 minutes at $25^{\circ} \mathrm{C}$ shaking at $100 \mathrm{rpm}$. Absorbance at $595 \mathrm{~nm}$ was measured in a Biotek EPOCH 116 plate reader with 2 measurements for each well. Each sample had at least four replicates within the 117 plate and each media formulation had at least four uninoculated wells that served as negative controls. The average absorbance of uninoculated wells was subtracted from sample biofilm wells.

Measuring cell growth in milk protein supplemented media. To test for the effects of milk protein on growth of $P$. aeruginosa, $S$. marcescens, Aeromonas sp. and F. columnare, we measured 121 growth in R2B supplemented with $0.1 \%, 0.2 \%$ and $0.4 \%$ milk protein in 24 well microtiter plates. 122 We intentionally selected low concentrations at which milk protein is completely soluble. At 123 higher concentrations $(>1 \%)$ milk protein solutions are colloidal, making it difficult to measure 124 optical density. Growths were performed in 24 well microtiter plates with 4x replication and 125 shaking at $100 \mathrm{rpm}$ on an orbital shaker at $25^{\circ} \mathrm{C}$. Optical density measurements were made at 0 , $126110 \mathrm{~min}, 210 \mathrm{~min}, 300 \mathrm{~min} 390 \mathrm{~min} 450 \mathrm{~min}$ and 24 hours on a Biotek EPOCH plate reader at $127600 \mathrm{~nm}$. At 24 hours the wells were tested for biofilm formation as described above. Uninoculated 128 controls were subtracted from growths at each time point and in biofilm quantitation. Uninoculated 129 controls for each protein concentration were also replicated $\mathrm{x} 4$.

130 Determining Viable Cells Within Biofilm. To determine the viable cell count within biofilm 131 formed in supplemented and unsupplemented media, cultures of P. aeruginosa PA01, Aeromonas 
$132 \quad 060628-1$ and $S$. marcescens RL-5 were established in 24 well plates by inoculating $700 \mu 1$ of R2B $133 \pm$ milk protein with $100 \mu \mathrm{l}$ of overnight culture. Control wells contained $800 \mu \mathrm{l}$ of uninoculated

134 media. Plates were sealed with sterile foil and incubated for 24 hours shaking at $100 \mathrm{rpm}$ and $25^{\circ} \mathrm{C}$.

135 These experiments were set up in duplicate so that biofilm determination with crystal violet 136 (Sigma) and viable cell counts could be performed in parallel. Each plate contained four replicates 137 of each strain and media combination. After 48 hours of growth, one plate was stained with crystal 138 violet as described above for quantitation of biofilm and the duplicate plate was used to determine 139 the viable cells count within biofilms, as follows. The plate was gently rinsed three times in sterile 140 water and the washed biofilm was scrapped off using $600 \mu 1$ of sterile water and a sterile applicator.

141 The cell slurry was transferred to $1.5 \mathrm{ml}$ eppendorf tubes, vortexed to break up cell aggregates and 142 10-fold serially diluted for plating onto R2A. Plating was in triplicate and CFUs are reported as 143 the total CFUs per well.

144 Determination of protein content in biofilm. To determine the protein concentration of 145 biofilms, 24 well plates were used as described. In this experiment we tested P. aeruginosa, Aeromonas 060628-1 and F. columnare. Biofilm of P. aeruginosa and Aeromonas were prepared in $\mathrm{R} 2 \mathrm{~B}$ and $\mathrm{R} 2 \mathrm{~B}-5 \% \mathrm{MP}$ while $F$. columnare was tested in R2B-1\%MP. Duplicate plates were 148 inoculated so that both protein concentration and crystal violet staining could be tested in parallel. 149 In each plate, all unique media conditions were replicated four times. After 24 hours of incubation at $25^{\circ} \mathrm{C}$ and shaking at $100 \mathrm{rpm}$, one plate was stained with crystal violet (as described above) and the duplicate plate was used to determine protein content within biofilm as follows. After 24 hours

152 of incubation the media was removed and the wells were washed twice by adding $800 \mu 1$ of sterile 153 water and shaking at $100 \mathrm{rpm}$ for 2 minutes. The final wash was removed and $200 \mu \mathrm{l}$ of sterile 154 water was added to each well. The biofilm was removed by manually scrapping with a sterile glass 155 rod and then transferred to a $1.5 \mathrm{ml}$ Eppendorf tube. The solution was vortexed and centrifuged at $1564^{\circ} \mathrm{C}$ and12,000 rpm for 20 minutes in a microfuge to remove the cells. The supernatant was 157 transferred to a new tube and $400 \mu \mathrm{l}$ of $100 \%$ Ethanol was added to precipitate protein. After 158 overnight storage at $-20^{\circ} \mathrm{C}$, the tubes were centrifuged at $4^{\circ} \mathrm{C}$ and $12,000 \mathrm{rpm}$ for 20 minutes to 159 pellet all protein. The supernatant was decanted and the pellets were air dried for 15 minutes and 160 then resuspended in $150 \mu \mathrm{l}$ of $1 \mathrm{x}$ PBS. To determine the protein concentration in these samples 161 the Coomassie protein assay (Thermo-Scientific) was employed, using the vendors recommended 162 protocol. Briefly, $150 \mu 1$ of Coomassie reagent plus $150 \mu 1$ of sample was added to a microtiter 
163 plate well, mixed and incubated for 10 minutes in the dark. The plate was read at $595 \mathrm{~nm}$ using a

164 Biotek EPOCH plate reader. The standard curve was as recommended by the vendor.

165 Confocal microscopy. A two-well chamber (Lab-TekII, Nalge Nunc International,USA) was

166 inoculated with $700 \mu \mathrm{L}$ of media and $100 \mu \mathrm{l}$ of $P$. aeruginosa or F. columnare. 5\% Skim Milk

167 Protein at 1/2x Tryptic Soy Broth (Becton, Dickinson and company, France) medium and $100 \mu \mathrm{L}$

168 of F. columnare overnight broth. The chamber was then wrapped in Parafilm (Bemis, USA) to

169 seal it. Next, the sample was incubated for 72 hours at 100 RPM. At 48-hour incubation the media

170 was gently removed and new $700 \mu \mathrm{L}$ of fresh medium was added into the wells. At 72 hours, the

171 medium was removed and discarded, and the chamber was gently washed 3 times with $1 \mathrm{~mL}$ of

172 sterile water. $1 \mathrm{~mL}$ of fluorescent solution containing $0.5 \mathrm{~mL}$ of 20x Nano Orange dye (Molecular

173 Probes Protein Quantitation Kit N10271) and 0.5mL of FM4-64 dye (Molecular Probes FM4-64)

174 was added into one well and incubated in the dark for five minutes. The well was washed with 1

$175 \mathrm{~mL}$ of sterile water two times. The sample was kept hydrate during microscopy. A confocal

176 microscope (Olympus FluoView FV1000) was used for imaging at 20x and 90x.

177

178

179

180

181

182

183

184

185

186

187

188

189

190

191

192

193

194

\section{RESULTS}

During the screening of a variety of environmental conditions designed to stimulate the formation of biofilm by soil isolates of Serratia, we detected a significant increase in biofilm when our standard growth media, R2B, was supplemented with milk protein (MP). Using standard media-grade skim milk protein (Hardy Diagnostics) at 5\%, biofilm formation of 16 independently isolated soil Serratia strains increased significantly. In Figure 1 we show the response of five Serratia strains to media supplemented with different concentrations of milk protein $(0.05,0.5$, 2.5 and 5.0\%). All five isolates responded to 5\% MP supplementation with a ten-fold increase in biofilm formation. All remaining isolates responded with similar increases (data not shown). In our biofilm assays we routinely use Pseudomonas aeruginosa PAO1 as a positive control. Under all conditions we have tested, PA01 produced a robust biofilm when grown on R2B or TSB but had little response to the presence of exogenous protein when at $0.5 \%$ or greater and, in many of our assays, high concentrations of protein in the media slightly inhibited biofilm formation by $P$. aeruginosa.

To extend these observations to other species we tested the ability of 5\% MP to stimulate biofilm production in 200 freshwater bacterial isolates. In Figure 2 we report on 48 randomly picked isolates that were selectively isolated on Pseudomonas isolation agar and were therefore 
195 resistant to irgasan, a broad spectrum antimicrobial that targets fatty acid synthesis in bacteria.

196 Among these isolates, 14 showed substantial increase in biofilm production in milk protein

197 supplemented media at least 2-fold greater than the unsupplemented control (eg. one Yersinia,

198 Shewanella and Rahnella). Of 13 Pseudomonas isolates, only two showed more than a 2-fold

199 increase in biofilm with protein-supplemented media. Of the eight genera in this test, Aeromonas

200 consistently showed a robust response to exogenous protein in the media. Six of the twenty

201 Aeromonas isolates had 10-fold increases in biofilm formation and 8/20 had at least a 2-fold 202 increase.

203 We have tested several hundred freshwater isolates in this manner and when assaying that 204 many strains, we routinely make a single-pass evaluation with the crystal violet assay, accounting 205 for the lack of error bars in Figure 2. To statistically confirm our results, we examined six isolates 206 from this freshwater collection in greater detail, three Aeromonas, two Rahnella and one 207 Pseudomonas at four different concentrations of milk protein in TSB. These data, presented in 208 Figure 3, show that the Aeromonas isolates responded to MP concentrations of 1-5\% while a 209 freshwater Pseudomonas isolate revealed little response until 5\% and Rahnella was unresponsive. 210 To extend this analysis to isolates associated with eukaryotic hosts, we also investigated 211 the relationship between biofilm formation and exogenous protein in five isolates from fish, three 212 from humans and an E. coli strain from bovine. These data are presented in Figure 4. Among the 213 isolates from fish, F. columnare, Hydrogenophaga, Brevundimonas responded strongly and 214 positively to exogenous protein by producing abundant biofilm, but at different optimal protein 215 concentrations (Fig 4. Panel A). F. columnare and Hydrogenophaga had greatest biofilm 216 productivity at 1\% while Brevundimonas was more productive at 5\%. Pseudomonas C22 does not 217 form abundant biofilm in unsupplemented media and productivity increased only modestly at $1 \%$ 218 and 5\% MP. Acidovorax was unresponsive to exogenous protein. Panel B reports on the human 219 and bovine isolates. Aeromonas sp, an unpigmented Serratia and a low biofilm forming E. coli 220 were isolated from human feces and had varied response to exogenous protein. Both Aeromonas 221 and the Serratia isolates responded with greater biofilm productivity at $1 \%$ and 5\% but E. coli was 222 unresponsive. Included in this experiment was one of our soil Serratia isolates (RL-4) for 223 comparison. Interestingly, biofilm formation by the $E$. coli isolate from bovine, identified as a high 224 biofilm forming strain, was inhibited in media supplemented with $1 \%$ and 5\% MP. Note that this 225 experiment was conducted in LB broth without salt to mimic the conditions used in the initial 
226 characterizations of the E. coli strains. Both P. aeruginosa PA01 and our soil Serratia RL-4 had 227 biofilm profiles in supplemented and unsupplemented TSB similar to what we have seen in R2B.

As can be seen from these biofilm assays, in some cases the amount of crystal violet staining material was quite large. In many of the Aeromonas strains tested an opaque disk formed at the bottom of the wells, particularly if the incubation period was extended to 48 hours and the 96 well format was used. An obvious concern was the possibility that crystal violet was staining protein and biofilm matrix atypically and providing a false positive for biofilm formation. To test for this, we ran several analyses in 24-well microtiter plates that prevented the formation of any opaque disk by virtue of the large well diameter. In these experiments, we measured biofilm formation using crystal violet and performed viable plate counts on biofilm from replica plates.

236 These data are presented in Figure 5 and show that, as observed above, both Aeromonas and 237 Serratia responded strongly to exogenous protein, producing at least a 10-fold increase in crystal 238 violet signal while Pseudomonas had little response. The cell viability from a replica plate revealed

239 a 1.2-3 order of magnitude increase for Serratia and Aeromonas when grown with 5\% exogenous 240 protein, while $P$. aeruginosa had a robust viable count in the absence of protein and only a modest 241 increase with protein when compared with Aeromonas.

An obvious question regarding the effect of exogenous protein on the formation of biofilm 243 is whether the biofilm becomes enriched in protein. To test for this, we established biofilm in 24 244 well plates (4 replicates of each strain on a plate) and replicated the whole plate so that both biofilm 245 formation and the amount of protein within the biofilm matrix could be measured. Because of our 246 interest in fish pathogens we tested Aeromonas and F. columnare with $P$. aeruginosa as our 247 positive control. The results are presented in Figure 6. As shown previously, both Aeromonas and $248 F$. columnare responded strongly to exogenous protein by producing more biofilm while $P$. aeruginosa PA01 was unresponsive. In this test, we used the optimal protein concentrations of 5\% for Aeromonas (and Pseudomonas) and 1\% for F. columnare. The biofilm from the replica plate was washed and manually scrapped from the wells and the protein concentration was determined 252 using the Bradford assay, after removing the cells by centrifugation. The amount of protein 253 detected in the biofilm for $P$. aeruginosa was 8.2 and $5.4 \mu \mathrm{g} / \mathrm{ml}$ for growth without and with 254 protein, respectively. For Aeromonas, the increase in biofilm in response to exogenous protein was 255 accompanied by an increase in matrix protein concentration from 0.55 to $47.3 \mu \mathrm{g} / \mathrm{ml}$. For $F$. columnare, the 20 -fold increase in biofilm was accompanied by a nearly 20 -fold increase in matrix 
protein $(0.18>3.11 \mu \mathrm{g} / \mathrm{ml})$. The optical densities of the cultures are revealing as well. As expected, the initial OD of cultures in unsupplemented media was relatively low, representing a 1:8 dilution from overnight cultures, but clear evidence of growth was detected after 24-hour incubation. The initial OD of the protein-supplemented wells was dominated by the opacity contributed by the milk protein, $\sim 1.7$ for a $5 \%$ solution and $\sim 0.5$ for a $1 \%$ solution. After incubation for 24 hours the OD of the $P$. aeruginosa wells dropped to 0.45 , suggesting the presence of protease activity. Presumptive protease activity was also detected in the $F$. columnare wells, evidenced by a drop in OD from 0.5 to 0.16 . Interestingly the wells containing Aeromonas showed no reduction in OD.

To determine the effect of exogenous protein on cell growth we incubated $P$. aeruginosa, $S$. marcescens, Aeromonas strain 060628-1 and F. columnare strain 090702-1 at three concentrations $(0.1 \%, 0.2 \%$ and $0.4 \%)$ of milk protein in R2B and monitored growth by optical density at $600 \mathrm{~nm}$. Low concentrations were selected to avoid colloidal solution conditions present at higher concentrations. P. aeruginosa grew well under these experimental conditions but optical density was diminished in a concentration dependent manner when the media was supplemented with protein (Panel A, Fig. 7). In contrast, S. marcescens (Panel B, Fig 7) grew robustly, regardless of the exogenous protein through $450 \mathrm{~min}$. Statistical differences were detected only after 24 hours of growth when exogenous protein appeared to modestly boost growth. Aeromonas grew slowly (Panel C, Fig 7) through 450 minutes with no appreciable difference with protein addition. The greatest growth was between 450 min and 24 hours. At 24 hours growth was inhibited at $0.4 \%$ exogenous protein. F. columnare grew well in the absence of exogenous protein and poorly, if at all, in its presence (Panel D, Fig 7). The tendency of this strain to form aggregates in solution accounted for the substantial inter-replicate variability. After 24 hours the plates were processed for biofilm formation (Figure 8). P. aeruginosa PA01, as mentioned above, is a robust biofilm

280 forming strain. Under conditions of growth in this experiment, enhanced biofilm productivity was 281 detected at all concentrations of exogenous protein. While $S$. marcescens grew vigorously, biofilm 282 productivity was quite low at the tested protein concentrations. Aeromonas also lacked biofilm 283 productivity at the lower concentrations of protein but did increase substantially at $0.4 \%$ milk 284 protein, in spite of the apparent growth inhibition at this concentration. Biofilm production by $F$. columnare increased in a concentration dependent manner when the media was supplemented with 286 protein. This robust biofilm production was in contrast to pelagic growth which appeared inhibited 287 by exogenous protein. 
In addition to measuring the protein content with a standard Bradford assay we used nanoorange to visualize the biofilm-associated protein. Using the standard microtiter plate protocol, we established biofilm on sterile coverslips with and without exogenous milk protein (1\%) using $P$. aeruginosa and $F$. columnare as the test strains. After growth, the biofilm was washed with sterile water (x3) and stained with Nano-orange and FM4-64 using the vendors protocol. The biofilm was viewed on an Olympus FluoView FV1000 Confocal Microscope at 20X and 90X magnification (Figure 9). Numerous $P$. aeruginosa cells were detected at 20X magnification but there was little evidence of a robust contiguous biofilm. Intensely orange spots could be detected suggesting concentrations of protein spotted the surface. At 90X magnification well isolated cells were seen with little evidence of a protein matrix. In contrast, the biofilm formed by $F$. columnare showed a thick branched proteinaceous complex at 20X magnification. Cells were clearly outlined with the lipophilic FM4-64 stain at 90X magnification and showed morphological variation as describe previously (22). In addition, irregularly shaped orange forms as well as cells decorated with Nano-orange were detected.

marcescens isolated from soil. Different temperatures, carbon sources, nutrient availability, osmolarity and substrata were tested without effect on biofilm formation. However, one environment in which $S$. marcescens can colonize is the human respiratory system and this provided clues to a possible environmental signal initiating biofilm formation in Serratia. Alveolar fluid from human lungs is generally at 5-13\% protein (23). This environmental feature of the lung led us to test biofilm formation at several concentrations of protein and identify robust biofilm of S. marcescens at $5 \%$ milk protein. Moreover, the increase in biofilm productivity was frequently

312 an order of magnitude or greater above that observed in unsupplemented media. Our positive 313 control strain, P. aeruginosa PA01, appeared unresponsive to high concentrations of protein in the 314 medium.

315 These observations were extended to 48 freshwater isolates, four strains from sturgeon eggs

316 (17), two known fish pathogens, three strains isolated from human gut and one from bovine and 317 the results showed biofilm production that was dependent on two variables, species and protein 318 concentration (a total of 74 strains including the Serratia isolates). Based on these data Serratia 319 isolates from both soil and human gut were highly responsive to $5 \%$ exogenous protein, producing 
5 to 10 times the amount of biofilm that they made in unsupplemented media. In all cases tested,

321 Serratia required concentrations around 5\% and failed to respond to lower concentrations $(0.1 \%$,

$3220.2 \%, 0.4 \%, 0.5 \%, 1 \% \& 2 \%$ ). Aeromonas strains were also sensitive to exogenous protein in the

323 same manner, increasing biofilm production, although lower concentrations of protein $(0.4 \%-2 \%)$

324 would suffice for some strains. The one strain of $F$. columnare reported on herein was particularly

325 responsive to exogenous protein with an optimum at 1\% protein and evidence of increased biofilm

326 productivity at as low as $0.1 \%$ protein. Additional studies within the Flavobacterium and

327 Chryseobacterium lineages indicated that all isolates of $F$. columnare tested thus far are responsive

328 to $1 \%$ milk protein (Loch \& Marsh, unpublished). Biofilm production by P. aeruginosa PA01 was

329 unresponsive to high concentrations of protein (1\%-5\%) and showed growth inhibition but

330 enhanced biofilm production at low concentrations $(0.1 \%, 0.2 \% \& 0.4 \%)$. Those strains that

331 appeared unresponsive at high concentrations included freshwater isolates Kluyvera, Erwinia,

332 nearly all Pseudomonas (11 of 12), all Rahnella aquatilis isolates, 3 of 4 Yersinia isolates and

333 human and bovine E. coli isolates.

334 Protein as a surface conditioning agent. A number of investigators have reported that soluble

335 protein can serve as a "conditioner" to surfaces that enhance or inhibit the development of biofilm.

336 Frequently serum is used as a "natural" protein-containing solution to condition surfaces (total

337 protein in serum is typically $60-80 \mathrm{~g} / \mathrm{L}$ ). For example, Patel et al. (24) showed that initial binding

338 of $S$. epidermidis cells to hydrophobic polyurethanes was suppressed by serum at 2 hours but

339 enhanced when incubated for $24 \mathrm{hrs}$. The opposite trend was observed for hydrophilic surfaces

340 where serum inhibited biofilm formation. Similarly, Frade et al. (25) found that serum enhanced

341 biofilm productivity of Candida albicans on metallic and non-metallic surfaces. Finally, using

342 methodologies most similar to our approach, Kipanga et al. (26) demonstrated that polystyrene

343 microtiter plates (Costar) conditioned with foetal calf serum showed reduced biofilm formation by

344 C. albicans. These assays are in general difficult to compare given the diversity of surfaces, strains

345 and complexity of serum. The Patel et al. work used human serum diluted to $20 \%$ as the incubation

346 medium whereas Frade et al. and Kipanga et al. used undiluted foetal calf serum only to condition

347 surfaces, but not as the media of incubation. In contrast our experiments used microbiological

348 media grade skim milk protein, autoclaved separately from other media components to eliminate

349 any temperature induced media-protein interactions. Our fully constructed media containing

350 protein up to $5 \%$ was used as the incubation media in which biofilm was formed. The observations 
351 that different phylogenetic taxa have different optimal protein concentrations for growth, biofilm

352 formation and protein assembled into the biofilm matrix suggest that caution must be used in

353 drawing generalizations regarding the influence of serum (or alveolar fluid) on biofilm formation

354 by any single isolate. The various effective ranges of biofilm enhancement exhibited by different

355 strains in our study suggests that conditioning of the surface was not a relevant factor (our

356 concentrations were beyond saturation levels for polystyrene) but that species dependent

357 sensitivity to protein in the media was driving enhanced biofilm production at various protein

358 concentrations. Direct tests of milk protein as a surface conditioning agent for Serratia were

359 negative (data not shown).

360 Exogenous protein - a trigger or adjuvant to biofilm formation? As mentioned above, we 361 were particularly interested in identifying environmental triggers of biofilm formation. While our 362 results with exogenous protein are provocative in this regard, we cannot identify milk protein 363 supplement as a trigger as opposed to an adjuvant in biofilm formation. The experiments described 364 in Figures $5 \& 6$ clearly indicate that the addition of exogenous protein increased cell concentration within the biofilm matrix (and biofilm biomass as measured with crystal violet) as well as the concentration of matrix protein in A. salmonicida and F. columnare. A. salmonicida was particularly efficient at incorporating protein into the matrix, increasing 80-fold over controls

368 lacking milk protein. Interestingly, the primary strains of this study, P. aeruginosa, A. salmonicida, F. columnare and S. marcescens, produce extracellular proteases when grown on R2A or TSA plates with 5\% milk protein (data not shown). Other isolates of these strains have a welldocumented history of producing extracellular proteases (27-33). Consistent with this was our

372 observations in Fig. 6 that when cultivated in microtiter plates for biofilm production, both $P$.

373 aeruginosa and $F$. columnare reduced the opacity of exogenous protein in the media, indicating 374 that extracellular proteases were actively degrading milk protein under the conditions of our 375 biofilm test. However, A. salmonicida showed no such activity in broth but did add an abundance 376 of protein to the biofilm matrix, suggesting that exogenous protein was at least a biofilm adjuvant 377 for $A$. salmonicida. Concluding that exogenous protein is the environmental trigger for $F$. 378 columnare biofilm formation is consistent with the complete absence of detectable pelagic growth 379 in broth supplemented with the milk protein but with concurrent construction of abundant biofilm 380 and incorporation of substantial protein into the matrix. Nonetheless, we do not have direct 381 evidence that exogenous protein is an environmental trigger. Finally, we note that skim milk 
protein is a common microbiological media additive that is not well defined because of proprietary information claims. The protein concentration range that we employed is not attainable with pure casein.

Protein, Proteases and Virulence. Some proteases are identified as virulence factors in pathogens including Serratia (29) and Pseudomonas aeruginosa (30, 33). The simplistic view of these extracellular proteases is that they are foraging for nutrients and clear habitats to occupy as well as impeding host immune responses that are protein based. While extracellular proteases have been linked to biofilm formation in Enterococcus (34-36), from our observations it is unclear if extracellular proteases influence the formation of biofilm in P. aeruginosa, F. columnare, $S$. marcescens and A. salmonicida, under our experimental conditions. With a simple plate assay, we can detect extracellular proteases in these strains but the response to exogenous protein in the production of biofilm is strain specific and Aeromonas does not appear to degrade MP in broth when testing for biofilm. Whether or not the proteases generate small peptides that are triggers or adjuvants of biofilm production remains to be determined.

The host-pathogen evolutionary dance. The analogy of an arms race has been used repeatedly for host-pathogen interactions as they evolve over time (37-40). Within this construct, each actor endeavors to detect the strengths and weaknesses of the other and evolve a strategy that increases the odds of survival, usually at the other's expense. Biofilm is recognized as a strategic response of bacteria to host defenses in that it protects the inhabitants from antibiotics, host defensins, macrophages and eosinophil networks $(5,10,41,42)$. The studies herein began with $S$. marcescens isolated from soil, a habitat with its own unique set of challenges but one that does not usually include pockets with high concentrations of protein. However, S. marcescens is adaptable and can infect both nematodes and humans. In nematodes, infection can initiate in the gut after ingestion (43). Based on the results from our S. marcescens strains we would predict that biofilm would be stimulated upon contact with the high protein content of the intestine and the epithelial lining of the nematode (the initial targets for infections caused by A. salmonicida and F. columnare include the fins, gills and intestinal tract are all sites with elevated protein concentrations). Similarly, in the respiratory system of humans we would predict that $S$. marcescens would form

411 fluid and infections of the respiratory system, the lung, in contrast to our friendly media with 412 benign milk protein, is designed to be a hostile environment for microbes. The protein content of 
413 alveolar fluid is complex and contains many different proteins of which four proteins are abundant, 414 SP-A, SP-B, SP-C, SP-D, and were originally described as hydrophobic (B \& C) and hydrophilic 415 (A \& D) surfactants that facilitate gas exchange on the mucosal surface (44). These proteins can 416 represent up to $10 \%$ of the dry weight of bronchial lavage fluid (45). Of particular interest are SP417 A and SP-D, now recognized as collectins, that participate in host defense along with their role as 418 surfactants. Both bind bacterial LPS and in addition, SP-D binds peptidoglycan. These proteins 419 have also been implicated in clearance of pathogens, activation of macrophages, modulation of 420 inflammatory response and regulation of innate immunity functions in the lung (44-46). We posit 421 that the second virulence strategy of Serratia (and Aeromonas, and F. columnare) is the 422 sequestration of proteins from the environment of their host, into the biofilm matrix. This is 423 consistent with the biofilm matrix as a multifunctional extracellular 'organ' of a bacterial 424 consortium (47). Incorporation of substantial amounts of SP-A into the biofilm as a structural 425 component would locally reduce its concentration in alveolar fluid and mute the host's immune 426 response. Targeting SP-A has been previously documented for P. aeruginosa (48).

427 In demonstrating the substantial influence of exogenous protein on biofilm productivity we 428 hope that this stimulates further work on this aspect of biofilm formation. Responses to exogenous 429 protein appeared to be strain specific, suggesting that the different environments in which these 430 strains are colonizing may have a range of exogenous protein concentrations to which cognate 431 strains have adapted. Protein and/or peptides in the concentrations ranges where we have detected 432 enhanced biofilm formation would saturate protein binding sites on the cell surface. Some of these 433 sites, as in the case of Enterococcus $(34,49,50)$, are linked to two-component regulatory systems, 434 hence exogenous protein may be an environmental trigger for biofilm formation.

Acknowledgements. We thank the Department of Microbiology and Molecular Genetics for partial funding. The remaining funds came through the Water Science program at Michigan State University. This project was conducted almost entirely by undergraduates. The isolation of Serratia marcescens strains were performed in an undergraduate laboratory (MMG-302) at MSU. DY, JK, \& LB were undergraduates at MSU and responsible for Figures 1, 2, 3, 5 \& 6. MMC was a visiting undergraduate scholar from Brazil, supported by Science Without Borders funded by Coordination for the Improvement of Higher Education Personnel and performed experiments for Figures 4 \& 9); MS was a visiting undergraduate scholar from Kalamazoo College and performed the initial characterization of the $S$. marcescens isolates. 


\section{REFERENCES}

1. Whitehead KA, Verran J. 2015. Formation, architecture and functionality of microbial biofilms in the food industry. Current Opinion in Food Science 2:84-91.

2. Balcazar JL, Subirats J, Borrego CM. 2015. The role of biofilms as environmental reservoirs of antibiotic resistance. Frontiers in Microbiology 6 .

3. Costerton W, Cheng K-I, Geesey GG, Ladd TI, Nickel C, Dasgupta M, Marrie TI. 1987.

Bacterial biofilms in nature and disease. Ann Rev Microbiol 41:435-64.

4. Jacques M, Aragon V, Tremblay YD. 2010. Biofilm formation in bacterial pathogens of veterinary importance. Anim Health Res Rev 11:97-121.

5. Jamal M, Ahmad W, Andleeb S, Jalil F, Imran M, Nawaz MA, Hussain T, Ali M, Rafiq M, Kamil MA. 2018. Bacterial biofilm and associated infections. J Chin Med Assoc

6. Anderson OR. 2016. Marine and estuarine natural microbial biofilms: ecological and biogeochemical dimensions. Aims Microbiology 2:304-331.

7. Augimeri RV, Varley AJ, Strap JL. 2015. Establishing a Role for Bacterial Cellulose in Environmental Interactions: Lessons Learned from Diverse Biofilm-Producing Proteobacteria. Frontiers in Microbiology 6.

8. Kopf SH, Sessions AL, Cowley ES, Reyes C, Van Sambeek L, Hu Y, Orphan VJ, Kato R, Newman DK. 2016. Trace incorporation of heavy water reveals slow and heterogeneous pathogen growth rates in cystic fibrosis sputum. Proc Natl Acad Sci U S A 113:E110-6.

9. Costerton JW, Lewandowski Z, Caldwell DE, Korber DR, Lappinscott HM. 1995. MICROBIAL BIOFILMS. Annual Review of Microbiology 49:711-745.

10. O’Toole G, Kaplan H, Kolter R. 2000. Biofilm Formation as Microbial Development. Annu Rev Microbiol 54:49-79.

11. Pantanella F, Berlutti F, Passariello C, Sarli S, Morea C, Schippa S. 2007. Violacein and biofilm production in Janthinobacterium lividum. Journal of Applied Microbiology 102:992-999.

12. Sarkisova S, Patrauchan MA, Berglund D, Nivens DE, Franklin MJ. 2005. Calciuminduced virulence factors associated with the extracellular matrix of mucoid Pseudomonas aeruginosa biofilms. J Bacteriol 187:4327-37.

13. Patrauchan MA, Sarkisova S, Sauer K, Franklin MJ. 2005. Calcium influences cellular and extracellular product formation during biofilm-associated growth of a marine Pseudoalteromonas sp. Microbiology 151:2885-97.

14. Cruz LF, Cobine PA, De La Fuente L. 2012. Calcium increases Xylella fastidiosa surface attachment, biofilm formation, and twitching motility. Appl Environ Microbiol 78:132131 .

15. Zhou G, Shi QS, Huang XM, Xie XB. 2016. Proteome responses of Citrobacter werkmanii BF-6 planktonic cells and. biofilms to calcium chloride. Journal of Proteomics 133:134-143.

16. Ren GX, Fan S, Guo XP, Chen SY, Sun YC. 2016. Differential Regulation of c-di-GMP pestis. Frontiers in Microbiology 7. 
17. Fujimoto M, Lovett B, Angoshtari R, Nirenberg P, Loch TP, Scribner KT, Marsh TL. 2018. Antagonistic Interactions and Biofilm Forming Capabilities Among Bacterial Strains Isolated from the Egg Surfaces of Lake Sturgeon (Acipenser fulvescens). Microb Ecol 75:22-37.

18. Singh P, Teal TK, Marsh TL, Tiedje JM, Mosci R, Jernigan K, Zell A, Newton DW, Salimnia H, Lephart P, Sundin D, Khalife W, Britton RA, Rudrik JT, Manning SD. 2015. Intestinal microbial communities associated with acute enteric infections and disease recovery. Microbiome 3.

19. Wang Q, Garrity G, Tiedje J, Cole J. 2007. Naïve Bayesian Classifier for Rapid Assignment of rRNA Sequences into the New Bacterial Taxonomy. Appl Environ Microbiol 73:5261-5267.

20. Gouy M, Guindon S, Gascuel O. 2010. SeaView version 4 : a multiplatform graphical user interface for sequence alignment and phylogenetic tree building. Molecular Biology and Evolution 27:221-224.

21. Merritt JH, Kadouri DE, O'Toole GA. 2011. Growing and Analyzing Static Biofilms, p 1B.1.1-1B.1.18, Current Protocols in Microbiology doi:10.1002/9780471729259.mc01b01s22.

22. Bernadet JF, Bowman JP. 2006. The Genus Flavobacterium. In Martin Dworkin ME-i-C, Falkow S, Rosenberg E, Schleifer K-H, Stackebrandt E (ed), The Prokaryotes A Handbook on the Biology of Bacteria, Third Edition ed, vol 7.

23. Bicer EM. 2014. Compositional characterisation of human respiratory tract lining fluids for the design of disease specific simulants. Ph.D. King's College London, London.

24. Patel JD, Ebert M, Ward R, Anderson JM. 2007. S. epidermidis biofilm formation: effects of biomaterial surface chemistry and serum proteins. J Biomed Mater Res A 80:742-51.

25. Frade JP, Arthington-Skaggs BA. 2011. Effect of serum and surface characteristics on Candida albicans biofilm formation. Mycoses 54:e154-62.

26. Kipanga PN, Luyten W. 2017. Influence of serum and polystyrene plate type on stability of Candida albicans biofilms. J Microbiol Methods 139:8-11.

27. Cahill MM. 1990. VIRULENCE FACTORS IN MOTILE AEROMONAS SPECIES. Journal of Applied Bacteriology 69:1-16.

28. Defoirdt T. 2014. Virulence mechanisms of bacterial aquaculture pathogens and antivirulence therapy for aquaculture. Reviews in Aquaculture 6:100-114.

29. Hase CC, Finkelstein RA. 1993. BACTERIAL EXTRACELLULAR ZINCCONTAINING METALLOPROTEASES. Microbiological Reviews 57:823-837.

30. Lindsay S, Oates A, Bourdillon K. 2017. The detrimental impact of extracellular bacterial proteases on wound healing. International Wound Journal 14:1237-1247.

31. Newton JC, Wood TM, Hartley MM. 1997. Isolation and partial characterization of extracellular proteases produced by isolates of Flavobacterium columnare derived from channel catfish. Journal of Aquatic Animal Health 9:75-85.

32. Shoemaker CA, LaFrentz BR, Peatman E, Beck BH. 2018. Influence of native catfish mucus on Flavobacterium columnare growth and proteolytic activity. Journal of Fish Diseases 41:1395-1402.

33. Strateva T, Mitov I. 2011. Contribution of an arsenal of virulence factors to pathogenesis of Pseudomonas aeruginosa infections. Annals of Microbiology 61:717-732. 
34. Hancock LE, Perego M. 2004. The Enterococcus faecalis fsr Two-Component System Controls Biofilm Development through Production of Gelatinase. Journal of Bacteriology 186:5629-5639.

35. Thurlow LR, Thomas VC, Narayanan S, Olson S, Fleming SD, Hancock LE. 2010. Gelatinase Contributes to the Pathogenesis of Endocarditis Caused by Enterococcus faecalis. Infection and Immunity 78:4936-4943.

36. $\mathrm{Xu} \mathrm{W,} \mathrm{Flores-Mireles} \mathrm{AL,} \mathrm{Cusumano} \mathrm{ZT,} \mathrm{Takagi} \mathrm{E,} \mathrm{Hultgren} \mathrm{SJ,} \mathrm{Caparon} \mathrm{MG.} 2017$. Host and bacterial proteases influence biofilm formation and virulence in a murine model of enterococcal catheter-associated urinary tract infection. Npj Biofilms and Microbiomes 3.

37. Daugherty MD, Malik HS. 2012. Rules of engagement: molecular insights from hostvirus arms races. Annu Rev Genet 46:677-700.

38. Hall AR, Scanlan PD, Morgan AD, Buckling A. 2011. Host-parasite coevolutionary arms races give way to fluctuating selection. Ecol Lett 14:635-42.

39. Maor R, Shirasu K. 2005. The arms race continues: battle strategies between plants and fungal pathogens. Curr Opin Microbiol 8:399-404.

40. Stern A, Sorek R. 2011. The phage-host arms race: shaping the evolution of microbes. Bioessays 33:43-51.

41. Bjarnsholt T, Kirketerp-Moller K, Jensen PO, Madsen KG, Phipps R, Krogfelt K, Hoiby N, Givskov M. 2008. Why chronic wounds will not heal: a novel hypothesis. Wound Repair and Regeneration 16:2-10.

42. Hoiby N, Ciofu O, Johansen HK, Song Z-j, Moser C, Jensen PO, Molin S, Givskov M, Tolker-Nielsen T, Bjarnsholt T. 2011. The clinical impact of bacterial biofilms. International Journal of Oral Science 3:55-65.

43. Mallo G, Kurz C, Couillault C, Pujol N, Granjeaud S, Kohara Y, Ewbank J. 2002. Inducible Antibacterial Defense System in C. elegans. Current Biology, Vol 12, 1209 1214, 12:1209-1214.

44. Floros J, Wang GR, Mikerov AN. 2009. Genetic Complexity of the Human Innate Host Defense Molecules, Surfactant Protein A1 (SP-A1) and SP-A2-Impact on Function. Critical Reviews in Eukaryotic Gene Expression 19:125-137.

45. Goerke J. 1998. Pulmonary surfactant: functions and molecular composition. Biochimica Et Biophysica Acta-Molecular Basis of Disease 1408:79-89.

46. Haczku A. 2008. Protective role of the lung collectins surfactant protein A and surfactant protein D in airway inflammation. Journal of Allergy and Clinical Immunology 122:861879.

47. Flemming H-C, Wingender J. 2010. The biofilm matrix. Nature Reviews Microbiology 8:623-633.

48. Kuang ZZ, Hao YH, Hwang SH, Zhang SP, Kim E, Akinbi HT, Schurr MJ, Irvin RT, Hassett DJ, Lau GW. 2011. The Pseudomonas aeruginosa flagellum confers resistance to pulmonary surfactant protein-A by impacting the production of exoproteases through quorum-sensing. Molecular Microbiology 79:1220-1235.

49. Mohamed JA, Huang DB. 2007. Biofilm formation by enterococci. Journal of Medical Microbiology 56:1581-1588.

50. Mull RW, Harrington A, Sanchez LA, Tal-Gan Y. 2018. Cyclic Peptides that Govern Signal Transduction Pathways: From Prokaryotes to Multi-cellular Organisms. Current Topics in Medicinal Chemistry 18:625-644. 


\section{FIGURE LEGENDS}

Figure 1. Biofilm formation by $S$. marcescens soil isolates in response to elevated concentrations of milk protein in broth $(0.05 \%, 0.5 \%, 2.5 \% \& 5.0 \%)$. Incubation in microtiter plates was for 24 hours at $25^{\circ} \mathrm{C}$ on an orbital shaker at $100 \mathrm{RPM}$.

Figure 2. Biofilm formation by freshwater isolates in response to milk protein at $5 \%$ in broth. All isolates were from the Red Cedar River, East Lansing, MI. All strains were isolated from a direct plating of river water on Pseudomonas Isolation Agar.

Figure 3. Biofilm formation by six freshwater isolates in response to elevated protein concentrations in broth. Six isolates from the biofilm screening described in Fig. 2 were tested for biofilm production at four different concentrations of milk protein $(0.5 \%, 1.0 \% .2 .0 \%$ and $5.0 \%)$ in TSB.

Figure 4. Biofilm formation by bacterial isolates from lake sturgeon eggs, Homo sapiens and Bovine. P. aeruginosa PA01 was used as a positive control for biofilm formation. Panel A; isolates from fish (F. columnare 090702-1, Hydrogenophaga F14, Brevundimonas F16, Acidovorax F19, and Pseudomonas $\mathrm{C} 22$ ) tested on R2Broth with $1.0 \%$ and $5.0 \%$ milk protein supplemented media. Panel B. Biofilm assay performed in $\mathrm{LB}$ broth without $\mathrm{NaCl}$ at $1 \%$ and $5 \%$ milk protein on Aeromonas, unpigmented Serratia and E. coli from H. sapiens and E. coli from Bovine.

Figure 5. The effect of exogenous protein on the concentration of cells within biofilm. These assays were performed in 24 well plates in R2Broth (gray) and R2Broth supplemented with 5\% milk protein (black).

Figure 6. The effect of exogenous protein on the protein concentration within biofilms. These experiments were performed in 24 well plates ( 4 replicates for each treatment) and each plate was replicated for measuring biofilm (crystal violet) and protein (Bradford assay). P. aeruginosa PA01 and Aeromonas strain 060628-1 were tested at 5\% milk protein and F. columnare 090702-1 was tested at $1 \%$ milk protein.

Figure 7. The effect of exogenous protein on growth of $P$. aeruginosa PA01, S. marcescens RL-5, Aeromonas strain 060628-1and F. columnare 090702-1. Growth was measured in R2Broth unsupplemented and supplemented with $0.1 \%, 0.2 \%$ and $0.4 \%$ milk protein.

Figure 8. Quantitation of biofilm from growth experiment described in Fig. 7.

Figure 9. Confocal images of $P$. aeruginosa (A \& B) and $F$. columnare (C \& D) biofilm at $20 \mathrm{X}$ and $90 \mathrm{X}$ grown with $2.5 \%$ milk protein. 


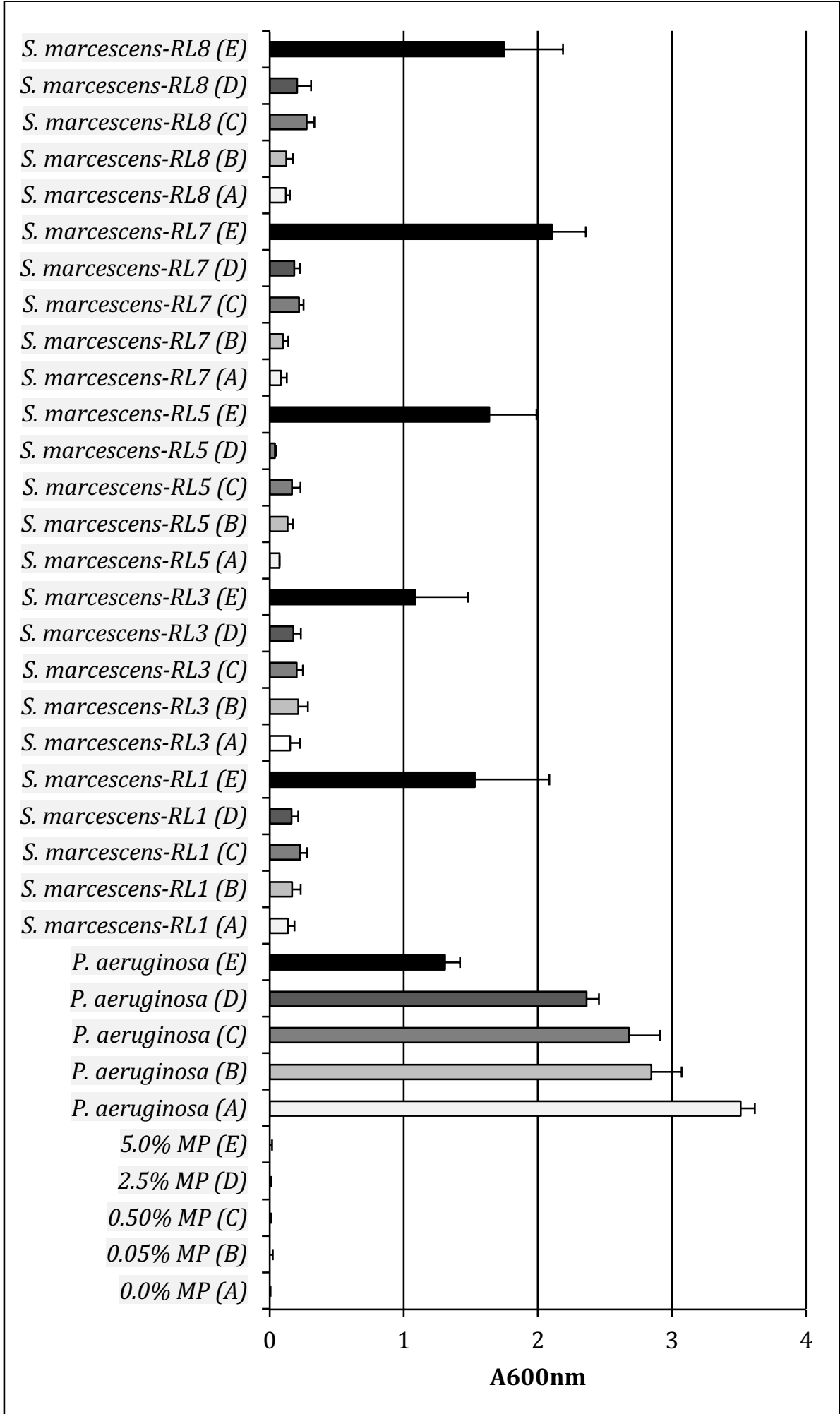

Figure 1 
bioRxiv preprint doi: https://doi.org/10.1101/683979; this version posted June 27, 2019. The copyright holder for this preprint (which was not certified by peer review) is the author/funder, who has granted bioRxiv a license to display the preprint in perpetuity. It is made available under aCC-BY-NC-ND 4.0 International license.

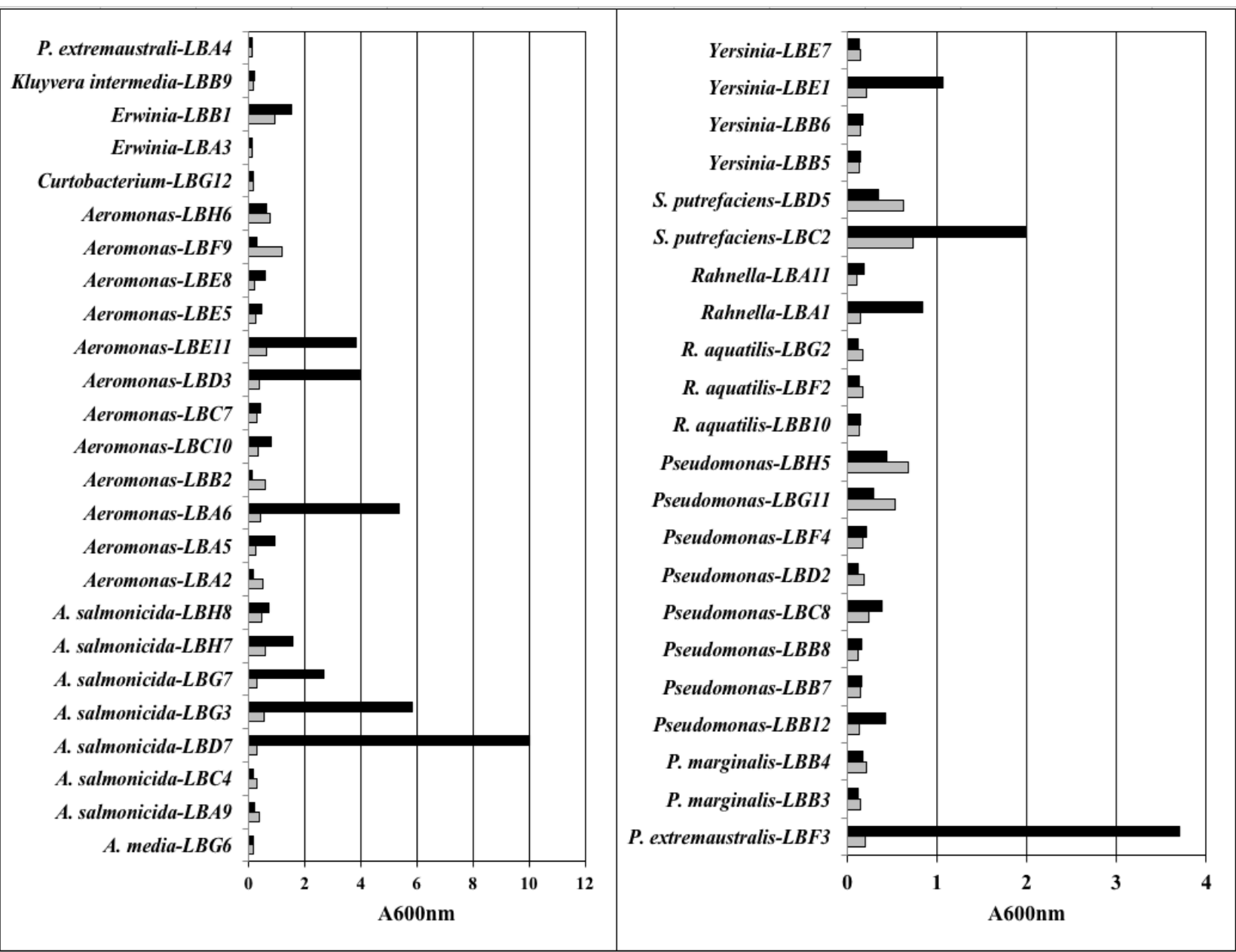


bioRxiv preprint doi: https://doi.org/10.1101/683979; this version posted June 27, 2019. The copyright holder for this preprint (which was not certified by peer review) is the author/funder, who has granted bioRxiv a license to display the preprint in perpetuity. It is made available under aCC-BY-NC-ND 4.0 International license.

636

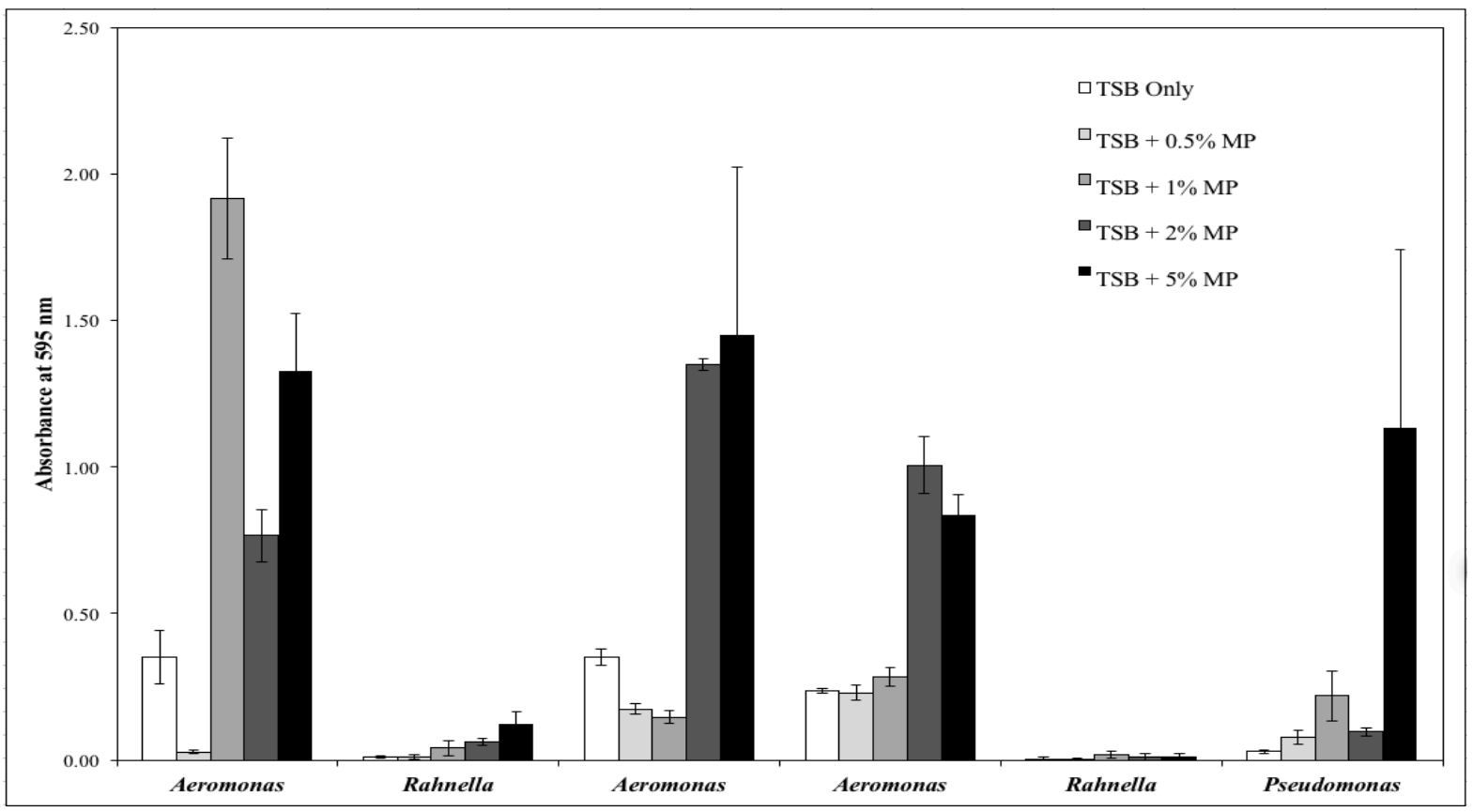

637

638

639

Figure 3

640

641

642

643

644

645 
bioRxiv preprint doi: https://doi.org/10.1101/683979; this version posted June 27,2019 . The copyright holder for this preprint (which was not certified by peer review) is the author/funder, who has granted bioRxiv a license to display the preprint in perpetuity. It is made available under aCC-BY-NC-ND 4.0 International license.
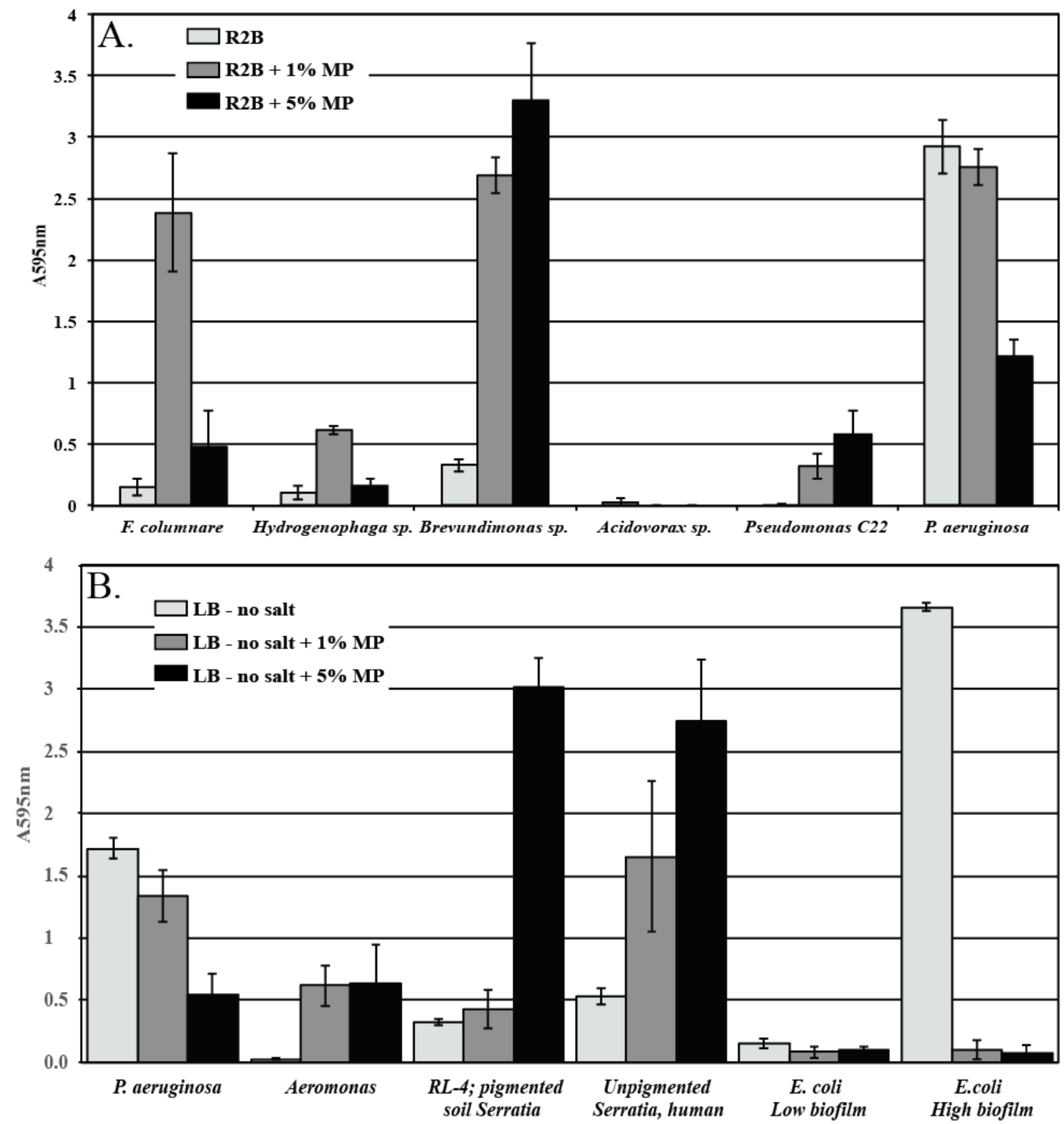

Figure 4 
bioRxiv preprint doi: https://doi org/10.1101/683979. this version posted June 27, 2019. The copyright holder for this preprint (which was not certified by peer review) is the author/funder, who has granted bioRxiv a license to display the preprint in perpetuity. It is made available under aCC-BY-NC-ND 4.0 International license.

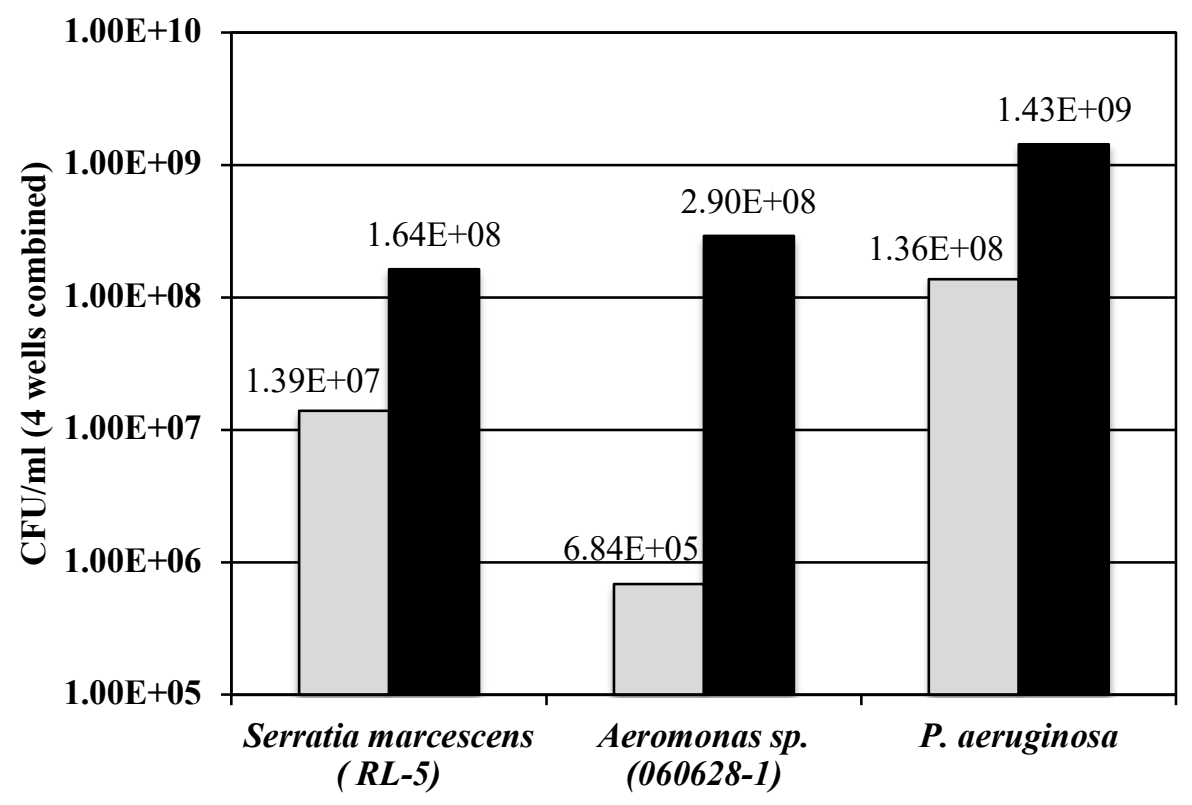




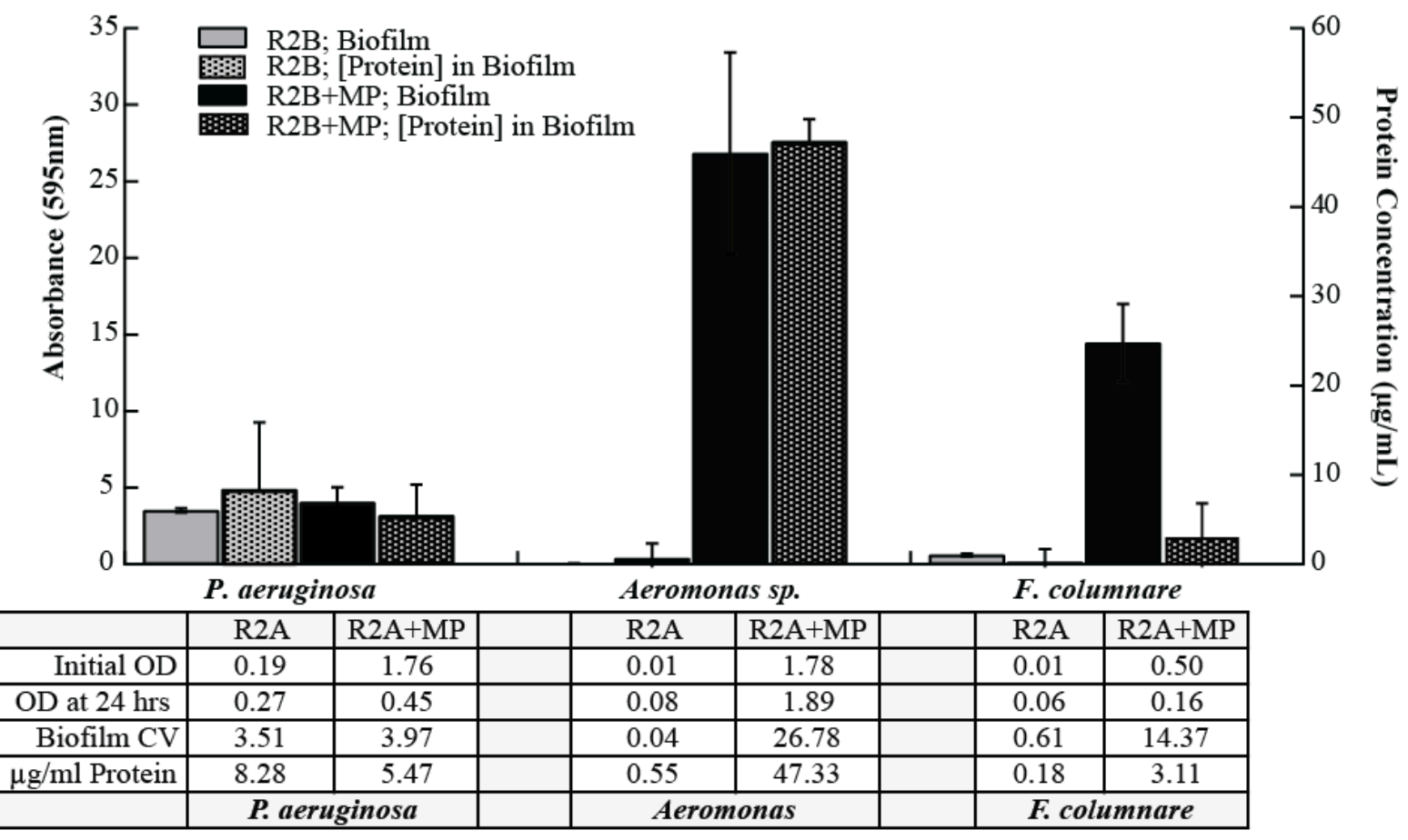


bioRxiv preprint doi: https://doi.org/10.1101/683979; this version posted June 27,2019 . The copyright holder for this preprint (which was not certified by peer review) is the author/funder, who has granted bioRxiv a license to display the preprint in perpetuity. It is made available under aCC-BY-NC-ND 4.0 International license.

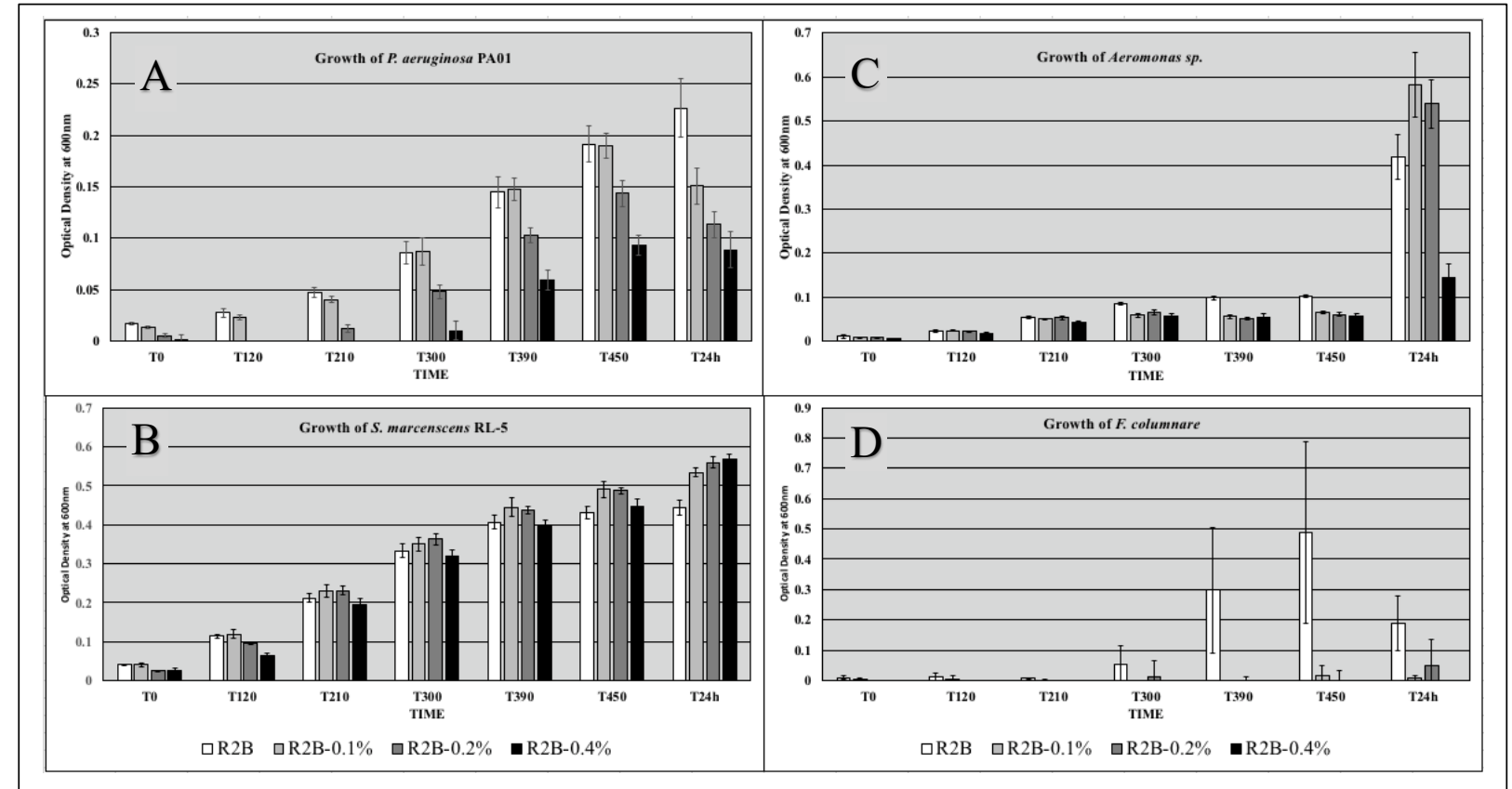

\section{Figure 7.}


bioRxiv preprint doi: https://doi.org/10.1101/683979; this version posted June 27,2019 . The copyright holder for this preprint (which was not certified by peer review) is the author/funder, who has granted bioRxiv a license to display the preprint in perpetuity. It is made available under aCC-BY-NC-ND 4.0 International license.

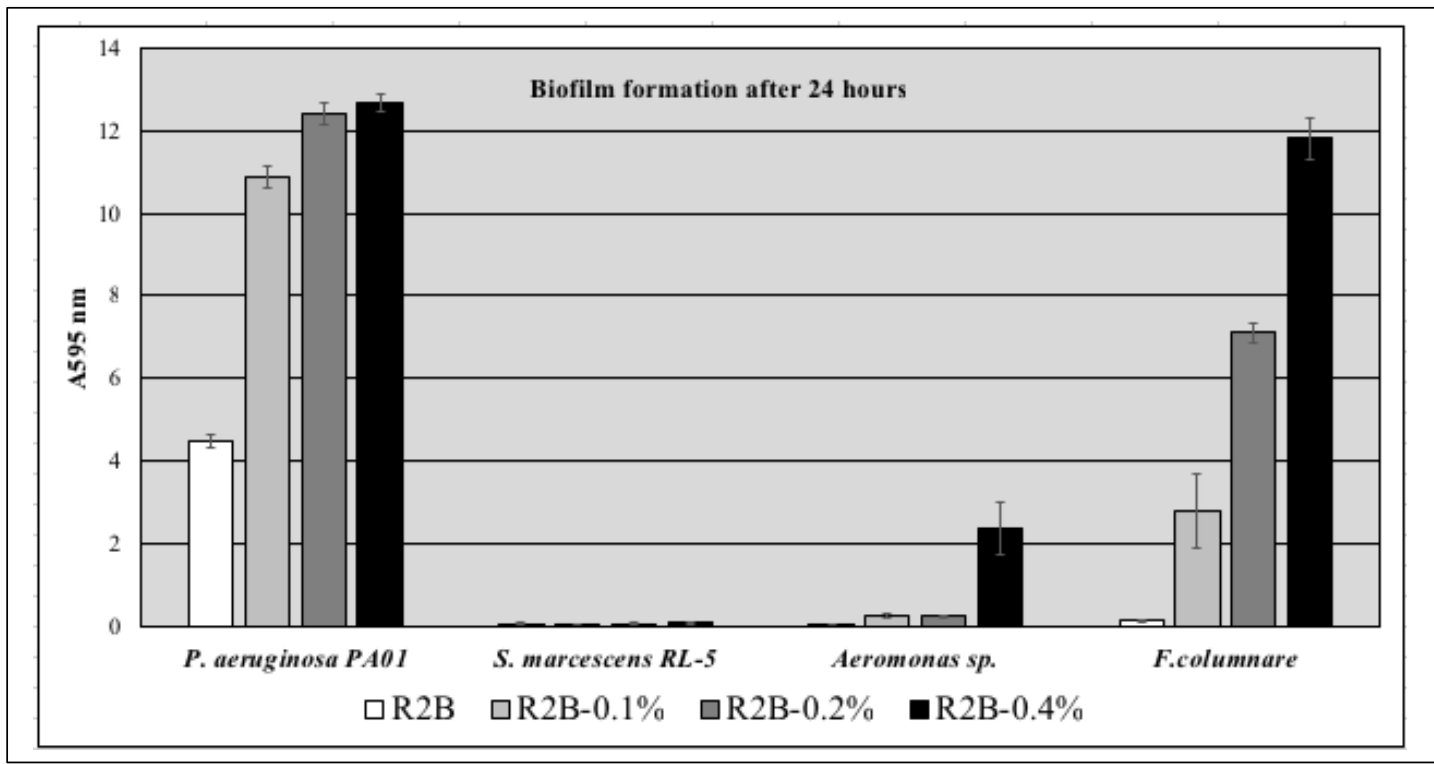

Figure 8. 
bioRxiv preprint doi: https://doi.org/10.1101/683979; this version posted June 27, 2019. The copyright holder for this preprint (which was not certified by peer review) is the author/funder, who has granted bioRxiv a license to display the preprint in perpetuity. It is made available under aCC-BY-NC-ND 4.0 International license.

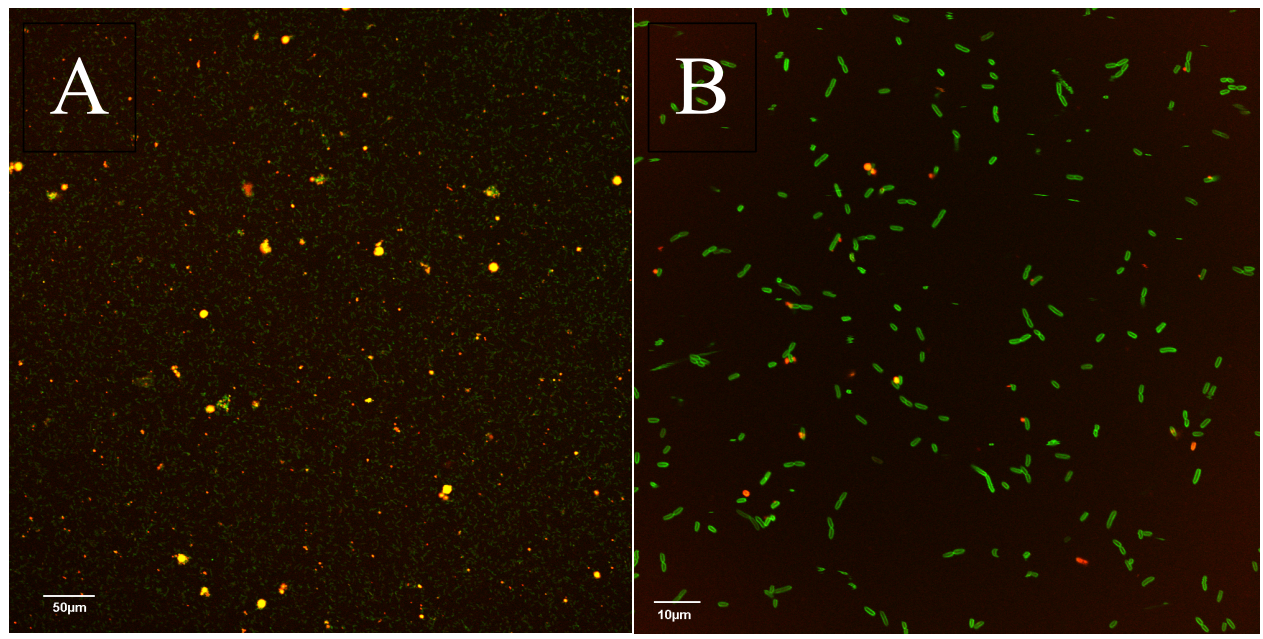

730

731

732

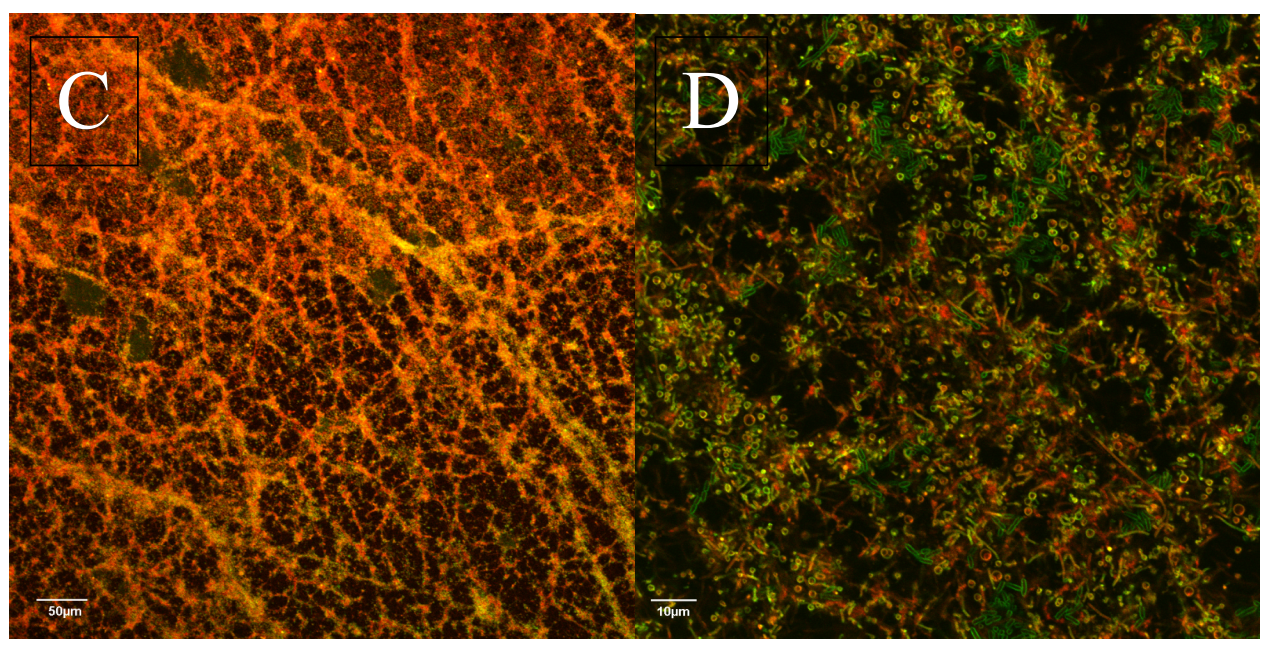

Figure 9 